\title{
Kapasitas Nabi Muhammad dalam Hadits-hadits Hukuman Mati bagi Pelaku Riddah Menurut Mahmûd Syaltût
}

\author{
Arif Wahyudi \\ (Jurusan Syariah STAIN Pamekasan, Jl. Panglegur KM. 4, Tlanakan Pamekasan \\ 69371,Email: arif@stainpamekasan.ac.id)
}

\begin{abstract}
Abstrak:
Hadits-hadits tentang hukuman mati secara umum berkualitas shahih dan diriwayatkan dengan banyak jalur sanad. Hadits-haditsnya pun dari sisi lain dapat dibagi menjadi dua macam: Pertama: Hadits qaulî yang berisi tentang sabda Nabi saw. "Barangsiapa yang berpindah agama maka bunuhlah". Ada pula beberapa riwayat dengan tambahan lafad "Meninggalkan agama dan berpisah dari jamaah muslimin". Kedua: Haditshadits fi lî dari Nabi saw. tentang beberapa orang murtad yang dibunuh karena kemurtadannya disertai dengan permusuhan dan tindak kriminal. Dari berbagai analisis disimpulkan bahwa Rasulullah saw. berkapasitas sebagai seorang imam ketika menyabdakan haditshadits tentang hukuman mati bagi pelaku riddah. Maka hukumannya merupakan ta`zir yang berlaku temporer tergantung situasi dan kondisi. Jika dipandang oleh imam, riddah membahayakan negara dan akidah kaum muslim, ia berhak menghukum dengan hukuman paling berat sekalipun, seperti yang telah dilakukan Ali bin Abi Thalib. Beliau menghukum dengan cara yang paling keras yaitu membakar.
\end{abstract}

\author{
Kata-kata Kunci: \\ Kapasitas Nabi, Hukuman Mati, Hadits-hadits Riddah, Mahmud Syaltut
}

\begin{abstract}
:
The hadiths about the death penalty in general are authentic and narrated by many chains. In this case, the hadiths can be divided into two kinds: First: Qaulî hadith which contains the saying of the Prophet Muhammad such as; "Whoever changed his (Islamic) religion, then kill him". In other narration, there is also some of the extra lafad "Leaving religion and separating from the assembly of Muslims". Second: fi $i \hat{\imath}$ hadiths of the Prophet. about some apostates that were killed for their apostasies were accompanied by hostility and crime. It can be concluded from various analyses that the Messenger of Allah
\end{abstract}


has the capacity of a priest when conveying hadiths about the death penalty for the perpetrators of apostasies. Thus, the punishment imposed is in the form of ta $z \hat{i} r$ which is on temporary basis depending on the circumstances. If riddah is considered by the priest as dangerous for the country and the faith of Muslims, then the punishment would be the most severe one, as done by Ali bin Abi Talib when he was sentenced to the harshest way, that is burning.

Keywords:

Prophet Capacity, Death Penalty, Hadiths on Apostasy, Mahmud Syaltut

\section{Pendahuluan}

Al-Qur'an dan Hadits, keduanya adalah sumber hukum Islam. Kalau al-Qur'an berbicara secara global dan dalam tataran konsep, maka Sunnah Nabi, merupakan petunjuk dalam tataran praktik secara rinci melalui kehidupan nyata Nabi sehari-hari, baik itu perbuatan, perkataan maupun taqrîr beliau terhadap suatu kejadian. Karena sifatnya yang praktis, mengikat serta bersentuhan langsung dengan kegiatan sosial dan keagamaan masyarakat, maka hadits tidak dapat mengelak dari perkembangan sosial keagamaan yang terjadi. Sementara, tidak seluruh hadits dijelaskan latar belakang kemunculannya (asbâb al-wurûd) untuk membantu mengetahui apakah hadits itu bersifat umum atau tidak dan bersifat selamanya atau tidak. Hal tersebut terkadang menjadi ajang tarik-menarik untuk memahami hadits antara realitas kekinian saat ini atau realita pada masa Nabi.

Untuk menjembatani kesenjangan masa tersebut, ulama telah banyak menawarkan berbagai metode memahami hadits. Mahmud Syaltut ${ }^{1}$ misalnya, berpendapat hadits-hadits Nabi, harus dicermati dalam kapasitas apa beliau ketika bersabda, mencontohkan, atau menyetujui. Apakah sebagai seorang rasul, seorang imam, seorang qadhi, atau bahkan seorang manusia biasa. ${ }^{2}$

1 Mahmud Syaltût adalah mantan Grand Syekh al-Azhar 1958-1963. Beliau adalah ulama yang moderat dan berpikiran maju dengan berbagai karya yang telah ditulisnya. Salah satu upaya yang pernah dilakukan ialah mendekatkan sunni dan syiah. Bahkan beliau berpandangan bolehnya beribadah dengan berpegang pada madzhab syiah Imamiyah.

2 Mahmûd Syaltût, al-Islâm Aqîdah wa Syarî̀ah, Vol. I, (Kairo: Dâr al-Syurûq, 1997), 499-501. 
Hadits-hadits yang bermuatan ajaran disabdakan dalam kapasitas Nabi sebagai pembawa risalah, seperti masalah-masalah akidah, halal-haram, dan tata cara peribadatan yang lain. Ajaranajaran yang bermuatan seperti ini menurut Syaltut adalah merupakan syariat umum yang berlaku selamanya. Hadits-hadits yang bermuatan kebijakan-kebijakan disabdakan dalam kapasitas beliau sebagai pemimpin kaum muslimin saat itu, seperti kebijakan beliau untuk mengirim pasukan, membelanjakan uang baitul al, dan lainlain, yang merupakan tugas seorang pemimpin untuk mengurus dan menjaga kepentingan rakyatnya. Hadits-hadits semacam ini menurut Syaltut, tidak merupakan syariat umum dan tidak dapat serta merta diamalkan dengan dalil Nabi, mengerjakan atau melakukannya kecuali dengan izin imam. Hadits-hadits dalam kapasitas beliau sebagai seorang hakim. Muatan hadits-hadits jenis ini tidak mengandung hukum umum sebagaimana jenis hadits yang kedua. ${ }^{3}$

Wacana tentang pembagian hadits berdasar kapasitas nabi saw., tidak diikuti Syaltut dengan memberi instrumen untuk memahami. Maka untuk menilai kapasitas Nabi. dalam menyabdakannya, penulis menggunakan beberapa pendekatan. Pertama: menggunakan pendekatan kebahasaan, semisal memahami kata-kata sukar, dan memahami kalimat. ${ }^{4}$ Kedua: menggunakan pendekatan muqâranah yaitu membandingkan satu matan dengan matan yang lain. Ketiga: dengan pendekatan historis, sosiologis maupun antropologis. Yaitu upaya memahami hadits khususnya dengan cara mempertimbangkan kondisi historis empiris yang melatarbelakangi munculnya hadits Nabi dan menyoroti dari sudut posisi manusia yang membawanya kepada perilaku itu, serta berupaya melihat praktik keagamaan yang tumbuh dan berkembang di masyarakat pada saat suatu hadits disabdakan ${ }^{5}$

Di antara topik-topik hadits, yang sebenarnya telah banyak dibahas oleh para ulama terutama dalam kitab-kitab fiqh, adalah hukuman mati bagi orang yang keluar dari agama Islam atau murtad. Tema ini bukanlah tema baru tapi masalah murtad ini seringkali

3 Ibid.

4 Lihat Muhammad Zuhri, Telaah Matan Hadits, (Yogyakarta: Lembaga Studi Filsafat, 2003), 54.

${ }^{5}$ Muhammad al-Fatih Surya Dilaga, Metodologi Syarah Hadits, Cet. I, (Yogyakarta: SUKA Press, 2012), 45-90. 
terulang di tengah masyarakat. Terlebih hak asasi manusia telah menjadi kesepakatan bangsa-bangsa di dunia. Hak-hak asasi manusia yang dideklarasikan tahun 1948 dan disetujui oleh sebagian besar negara di dunia, dalam sebuah pasal disebutkan, "Setiap orang mempunyai kebebasan atas pikiran, batin, dan agama, dalam hal ini termasuk kebebasan berganti agama atau kepercayaan". ${ }^{6}$

Hukuman mati bagi orang yang semata-mata murtad pun sejatinya akan mempertajam kekerasan atas nama agama, sebagai contoh Camellia Shehata, seorang istri pendeta gereja ortodox Mesir yang diisukan masuk Islam kemudian disiksa oleh suaminya, membuat hubungan antara umat Islam dan Kristen Ortodox yang sebelumnya rukun menjadi tegang. ${ }^{7}$ Sebaliknya, jika terjadi seorang muslim berpindah agama kemudian dihukum mati, reaksi yang sama akan terjadi dari pemeluk agama yang baru dianutnya dan pada akhirnya akan memicu kekerasan-kerasan yang tidak berujung, dan hal ini justru melenceng dari tujuan agama yang sesungguhnya.

Latar belakang tersebut di atas, memotivasi penulis untuk memahami hadits-hadits tentang hukuman mati bagi orang murtad secara komprehensif, tentu dengan perspektif yang berbeda. Kajian ini menggunakan pendekatan kualitatif. Adapun jenis penelitian yang digunakan adalah penelitian pustaka. Library Reseach dilakukan dengan menelaah naskah atau buku yang berkaitan dengan masalah yang diteliti baik langsung maupun tidak langsung.

\section{Pengertian Riddah dan Sebab-sebabnya}

Secara etimologi, kata riddah (ردة) berasal dari akar kata radda, yaruddu, riddah yang artinya sharafahu yaitu memalingkan, ‘arja`ahu yaitu mengembalikan, atau yaitu tertolak. ${ }^{8}$ Al-Qur'an biasanya menggunakan kata ini untuk makna orang yang kembali kepada

6 Paul William (ed.), The International Bill of Human Righs (Entwhistle Books, Glen Ellen, 1991), 8. Sebagaimana dikutip Suwoto Mulyosudarmo, Kebebasan Beragama Dalam Perspektif HAM, lihat Passing Over Melintasi Batas Agama, cet. III (Jakarta: PT. Gramedia Pustaka Utama, 2001), 147.

7http:/ / m.republika.co.id/indeks/hot_topic/camellia $\% 20$ shehata $\% 20$ guncang $\% 20 \mathrm{~m}$ esir 08 Mei 2011 (diakses 15 Agustus 2015)

8 Ibn Mandzûr, Lisân al-`Arab, (Beirut: Dâr Ihyâ' al-Turâts al-`Arâbî, 1999), Jilid V, 184. Lihat juga Luis Ma'lûf, al-Munjid fî al-Lughah al-A 'lâm, (Beirut: Dâr al-Masyriq, 2002), 255 
kemusyrikan, karena mayoritas inilah yang pernah dialami oleh mitra bicara al-Qur'an ketika turunnya. Tetapi setelah itu, kata riddah mengalami metamorfosis dan menjadi sebuah istilah populer yang dipahami dalam arti keluar dari Islam walaupun yang keluar itu belum pernah mengalami kemusyrikan sebelum ke-Islamannya. ${ }^{9}$

Secara terminologi, riddah adalah kembalinya seorang muslim yang berakal dan baligh, dari Islam kepada kekufuran dengan pilihannya sendiri, tanpa paksaan siapa pun, baik laki-laki maupun perempuan. ${ }^{10}$ Senada dengan pendapat tersebut, Wahbah Zuhayli mengatakan bahwa riddah ialah kembali dari agama Islam kepada kekufuran, baik dengan niat, perbuatan yang mengkafirkan maupun perkataan (baik perkataan tersebut tidak serius, sebagai sebuah ungkapan pengingkaran maupun sebagai keyakinan). ${ }^{11}$ Menurut Abd al-Qâdir al-'Audah, riddah adalah keluar dari Islam, yaitu meninggalkan Islam dengan melepaskan kebenarannya, dan keluarnya orang tersebut melalui tiga cara, yaitu dengan cara perbuatan, perkataan dan dengan keyakinan. ${ }^{12}$

\section{Matan Hadits-hadits Tentang Hukuman Mati Bagi Pelaku Riddah}

Hadits-hadits yang berhubungan dengan hukuman mati bagi orang murtad tersebar di berbagai kitab hadits. Rata-rata satu hadits yang berkenaan dengan tema ini diriwayatkan lebih dari satu jalur. Untuk efisiensi, penulis tidak akan membahas sanad hadits mengingat pemahaman hadits berangkat dari satu keyakinan bahwa hadits-hadits tentang tema yang akan dibahas, shahîh $\underline{h}$ secara sanad. Untuk memberi pemahaman yang utuh terhadap makna hadits maka sebagian hadits akan disertai dengan penjelasan makna mufradat-nya.

\section{Hadits: Barangsiapa yang Berpindah Agama maka Bunuhlah}

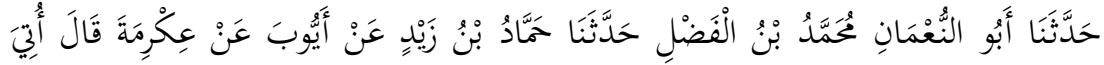

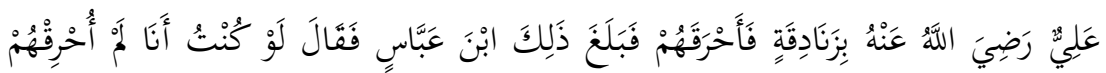

\footnotetext{
${ }^{9}$ M. Quraish Shihab, Tafsîr al-Mishbâh, Vol. III, (Jakarta: Lentera Hati, 2003), 120.

10 Sayyid Sâbiq, Fiqh al-Sunnah, Jilid III, (Kairo: Dâr al-Fath, 1998), 223.

11 Wahbah Zuhaylî, al-Figh al-Islâmî wa `Adillatuh, Juz VI, (Beirut: Dâr al-Fikr, 1996), 183.

12 'Abd al-Qâdir `Audah, al-Tasyrî̀ al-Jinầî al-Islâmî Muqârin bi al-Qânûn al-Wadh'î, Juz II, (Kairo: Mu'assasah al-Risalah, tth), 707.
} 


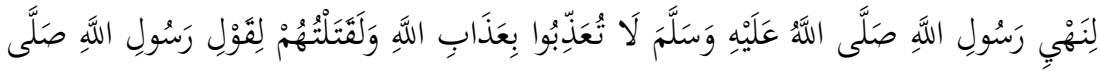

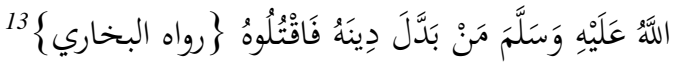

"... dari Ikrimah ia berkata, telah dibawa kepada Ali 'alaih al-Salâm orangorang zindiq, lantas Ali membakar mereka (orang-orang zindiq) lalu hal itu disampaikan kepada Ibn Abbâs, lalu Ibn Abbâs berkata, "Kalau aku tidak akan membakar mereka karena Rasulullah saw., bersabda: "Janganlah kalian mengadzab dengan azdab Allah", tapi aku akan membunuh mereka. Rasulullah saw. bersabda, "Barang siapa yang mengganti agamanya maka bunuhlah dia".

\section{Hadits: Murtad dan Meninggalkan Jama ah Halal Darahnya}

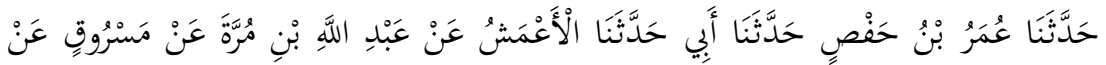

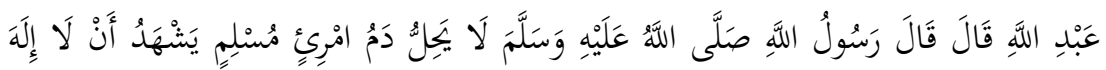

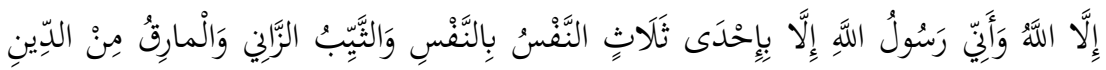

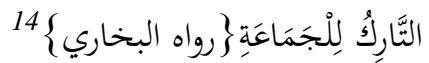

"...dari Abdillah ia berkata, Nabi saw., telah bersabda, “Tidak halal darah seorang muslim yang bersaksi bahwa tiada Tuhan selain Allah dan sesungguhnya aku adalah adalah utusan Allah kecuali karena salah satu dari tiga hal, karena membunuh orang

13 Muhammad Ismâîl Abû `Abd Allah al-Bukhârî al-Ja`fi, Shahîh al-Bukhârî (Beirut: Dâr al-Thauq al-Najâh, 1422 H.). Kitâb: Istitâbah al-Murtaddîn wa al-Mu`anidin wa qitâlihim, Juz 9, Bab: Hukm al-Murtad wa al-Murtaddah wa Istiâbatihim, 13. Hadits no. 6922 sesuai penomoran Fuad Abd al-Bâqî, Jumlah juz 9, selain itu hadits ini juga diriwayatkan oleh: Tirmidzî, Sunan al-Tirmidzî, Kitâb: al-Hudûd 'an Rasûlillah hadits o. 1378. al-Nasâ'̂,, Sunan al-Nasầî, Kitâb: Tahrîm al-Dâm hadits no. 3991/3992/3993/3994/3995/3996/3997. Ibn Mâjah, Sunan ibn Mâjah, Kitâb: al-Hudud hadits no. 2526. Ahmad, Musnad Ahmad, Min Musnad Banî Hâsyim hadits no. 1775/1802/2420/2813. CD Mausû̉ah al-Hadîts al-Syarîf (Kuwait: Global Islamic Software Company, 2000) terbitan ke II.

14 Al-Bukhârî Shahih Bukhârî... Kitâb: al-Diyâh, Bâb: Qauluh Ta'âlâ anna al-Nafs bi al-Nafs wa al-'Ain bi al-'Ain, juz 9 hlm. 5. hadits no: 6878. hadits ini juga diriwayatkan oleh. Tirmidzî, Sunan al-Tirmidzî, Kitâb: al-Diyât 'an Rasûlillah hadits no: 1322. Nasâ'î, Sunan al-Nasâ'̂, Kitâb Tahrîm al-Dam hadits no: 3951. Abû Daud, Sunan Abû Dâud, Kitab: alHudûd, hadits no: 3788. Ibn Mâjah, Sunan ibn Mâjah, Kitâb: al-Hudûid hadits no: 2525. Ahmad ibn Hanbal, Musnad Ahmad ibn Hanbal: Musnad al-Mukatstsirîn mi al-Shahâbah,

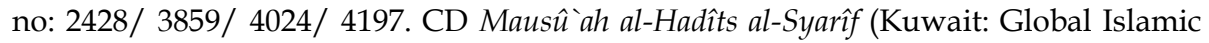
Software Company, 2000) terbitan ke II. 
lain, seorang janda yang berzina, dan meninggalkan agama dan meninggalkan jama`ah".

\section{Hadits VI: Kebijakan Abu Bakar dan Sikap Umar ibn Khatthâb}

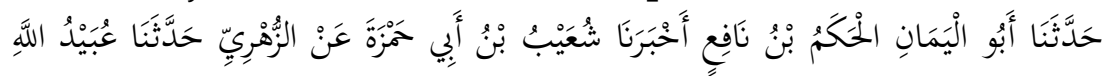

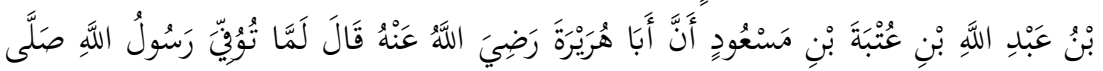

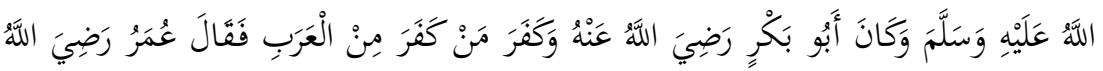

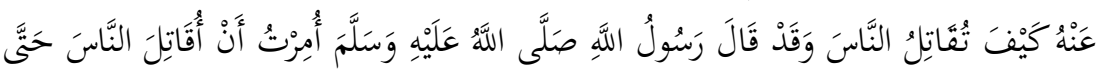

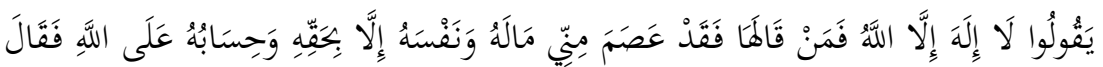

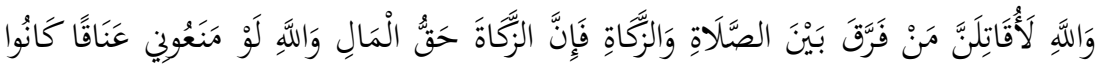

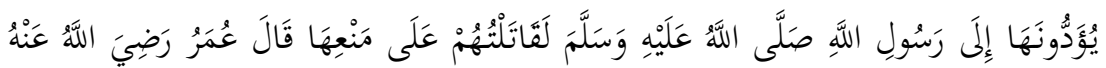

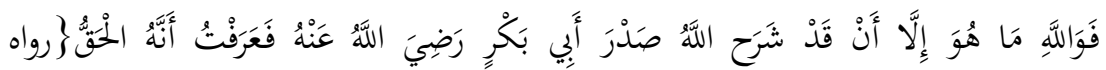

$$
\begin{aligned}
& 15\{\text { البخاري }
\end{aligned}
$$

"...Abu Hurairah radliallahu 'anhu berkata; Setelah Rasulullah shallallahu'alaihi wasallam wafat yang kemudian Abu Bakar radliallahu 'anhu menjadi khalifah maka beberapa orang 'Arab ada yang kembali menjadi kafir (dengan enggan menunaikan zakat). Maka (ketika Abu Bakar radliallahu 'anhu hendak memerangi mereka), 'Umar bin Al Khaththab radliallahu 'anhu bertanya: "Bagaimana Anda memerangi orang padahal Rasulullah shallallahu'alaihi wasallam telah bersabda: "Aku diperintahkan untuk memerangi manusia hingga mereka mengucapkan 'Laa ilaaha illallah'. Maka barangsiapa telah mengucapkannya berarti terlindunglah dariku darah dan hartanya kecuali dengan haknya sedangkan perhitungannya ada pada Allah".

15 Al-Bukhâri, Shahih Bukhârî... Kitâb: Zakâh, Bâb: Wujûb al-Zakât, juz 2, hlm. 105. Bukhâri juga meriwayatkan dalam kitâb: Zakâh hadits no: 1364, kitâb: Istitâbah alMurtaddîn hadits no: 6413, kitâb: al-Jihâd wa al-Siyar hadits no: 2727, kitâb: al-I tishâm bi al-Kitâb wa al-Sunnah hadits no: 6741. Hadits ini juga diriwayatkan Muslim, Shahîh Muslim, Kitâb: al-Îmân hadits no: 29. Tirmidzî, Kitâb: Sunan al-Tirmidzî, al-Îmân ‘an Rasûlillah hadits no: 2531/ 2532. al-Nasâ'î, Sunan al-Nasâ'̂, Kitâb: al-Zakâh 2400, Kitâb: al-Jihâd hadits no: 3039/ 3040/ 3041/ 3042/ 3043/ 3044, Kitâb: Tahrîm al-Dâm hadits no: 3906/ 3907/ 3908/ 3909/ 3910/3911/ 3912/ 3913/ 3914/ 3915. Abû Daud, Sunan Abû Daud, Kitâb: Zakâh hadits no: 1331, Kitâb: al-Jihâd hadits no: 2270. Ibn Mâjah, Sunan Ibn Mâjah, Muqaddimah hadits no70, Kitâb: al-Fitan hadits no: 3917. Ahmad ibn Hanbal, Musnad Ahamad ibn Hanbal, Musnad 'Asyrah al-Mubasysyirîn bi al-Jannah no: 64/ 112/ 232. CD Mausû̉ah al-Hadîts al-Syarîf (Kuwait: Global Islamic Software Company, 2000) terbitan ke II 
Arif Wahyudi

Maka Abu Bakar Ash-Shidiq radliallahu 'anhu berkata: "Demi Allah, aku pasti akan memerangi siapa yang memisahkan antara kewajiban shalat dan zakat, karena zakat adalah hak harta. Demi Allah, seandainya mereka enggan membayarkan anak kambing yang dahulu mereka menyerahkannya kepada Rasulullah shallallahu'alaihi wasallam, pasti akan aku perangi mereka disebabkan keengganan itu". Berkata, 'Umar bin Al Khaththab radliallahu 'anhu: "Demi Allah, ketegasan dia ini tidak lain selain Allah telah membukakan hati Abu Bakar Ash-Shidiq radliallahu 'anhu dan aku menyadari bahwa dia memang benar".

\section{Hadits VIII: Orang Nashrani yang Masuk Islam kemudian Murtad}

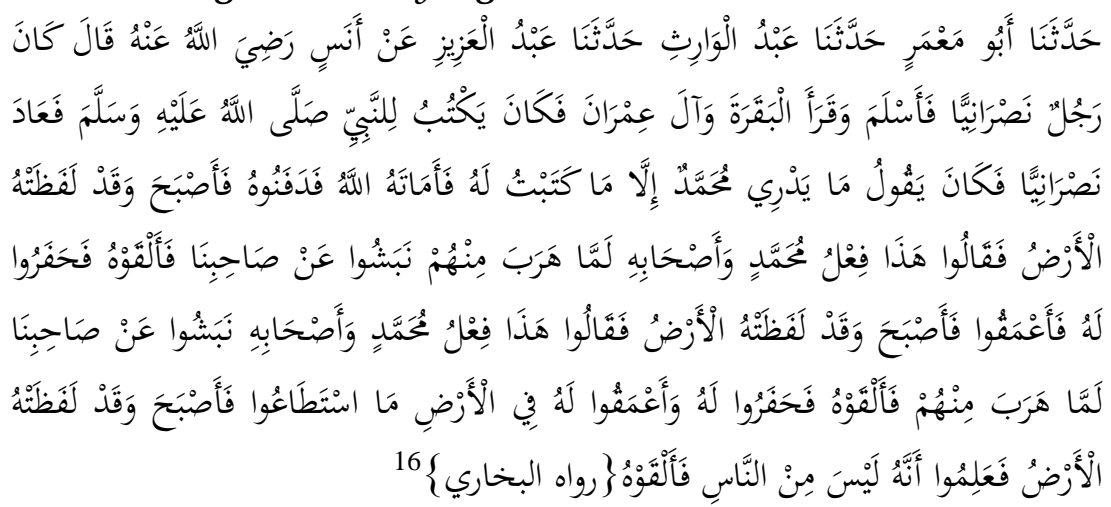

"... dari Anas r.a berkata, ada seorang laki-laki Nashrani masuk Islam lalu membaca surah Al Baqarah serta Ali 'Imran. Dia biasa menulis untuk Nabi shallallahu 'alaihi wasallam. Tapi kemudian dia kembali kepada agama Nashrani dan berkata; "Tidak ada yang diketahui Muhammad melainkan apa yang aku tulis untuknya". Kemudian Allah mewafatkannya lalu mereka (teman-temannya) menguburkannya. Pada keesokan harinya, jasadnya dimuntahkan oleh bumi, maka teman-temannya berkata; "Ini adalah perbuatan Muhamad dan sahabat-sahabatnya karena teman kita ini berpaling dari agama mereka, lalu mereka membongkar kuburannya dan mencampakkannya". Maka mereka kembali menguburkannya dan menggali lubangnya lebih dalam. Namun keesokan harinya, jasadnya kembali dimuntahkan oleh bumi, maka teman-temannya berkata; "Ini adalah perbuatan Muhamad dan sahabat-sahabatnya karena teman kita ini berpaling

16 Riwayat Bukhari, Shahîh al-Bukhârî... Kitâb: al-manâqib, Bâb: 'Alâmâh al-Nubuwwah fì al-Islâm, juz 4, hlm 202. Hadits ini juga diriwayatkan oleh Muslim dalam Shahîh Muslim, Kitâb: Shifât al-Munâfiqîn wa Ahkâmuhum, hadits no: 4987. Ahmad ibn Hanbal dalam Musnad Ahmad ibn Hanbal, Bâqî Musnad al-Mukatstsirîn no: 11769, 12846, 13084. CD Mausû̉ah al-Hadîts al-Syarîf (Kuwait: Global Islamic Software Company, 2000) terbitan ke II 
dari agama mereka, lalu mereka membongkar kuburan teman kita ini dan mencampakkannya". Maka mereka kembali menguburkannya dan menggali lubangnya lebih dalam lagi sebatas yang mereka mampu. Akan tetapi kembali pada keesokan harinya jasadnya itu dimuntahkan kembali oleh bumi hingga mereka menyadari bahwa kejadian itu bukan perbuatan manusia dan akhirnya mereka mencampakkannya begitu saja.

\section{Hadits IX: Orang Anshar Masuk Islam lalu Murtad dan Ingin} Kembali Islam

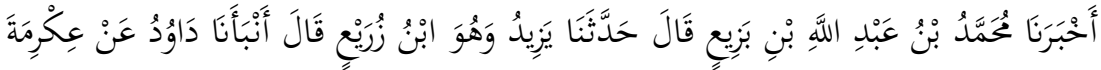

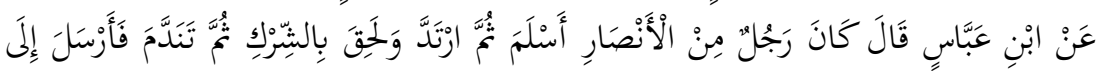

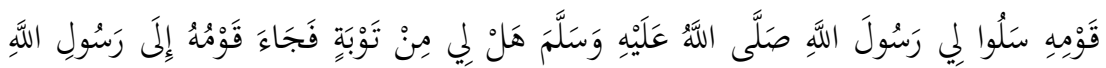

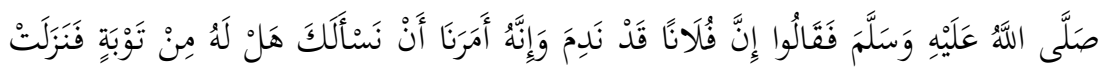

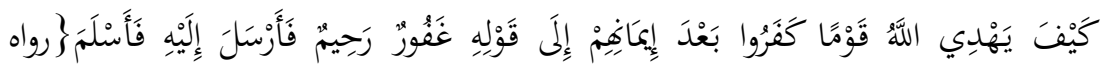

$$
\begin{aligned}
& 17\{\text { النسائي }
\end{aligned}
$$

"... dari Ibnu Abbas, ia berkata; ada seorang Anshor yang masuk Islam lalu ia murtad dan kembali bergabung dengan kesyirikan, kemudian ia menyesal dan pergi menemui kaumnya tanyakan kepada Rasulullah shallallahu 'alaihi wasallam apakah saya bisa bertaubat? Lalu kaumnya datang menemui Rasulullah shallallahu 'alaihi wasallam dan berkata sesungguhnya Fulan menyesal dan ia menyuruh kami untuk bertanya kepadamu apakah ia masih bisa bertaubat, lalu turunlah ayat كيف يهذ الله قوما كفروا بعد إيمانه hingga firmanNya 18 غفور رحيم Maha pengampun lagi Penyayang lalu beliau mengutus seseorang kepadanya dan ia pun masuk Islam.

\section{Kapasitas Nabi dalam Hadits-hadits tentang Hukuman Mati bagi} Pelaku Riddah (Perspektif Mahmud Syaltut)

Sebagaimana telah disebut sebelumnya, untuk menilai haditshadits tentang riddah memiliki konsekuensi hukum yang berlaku selamanya, temporer atau bahkan tidak mengandung hukum sama sekali, seperti yang telah disebut oleh Mahmud Syaltut. Mengingat Syaltut tidak memberi instrumen pemahaman maka hadits-hadits tersebut harus terlebih dahulu dipahami dengan berbagai pendekatan pemahaman.

\footnotetext{
17 Al-Nasâ'î, Sunan al-Nasâ'î, Kitab: Tahrîm al-Dam, Bab: Taubah al-Murtad, Juz 7, 107. 18 Qs Âli `Imrân 3: 86-89
} 


\section{Pemahaman Hadits-hadits tentang Hukuman Mati bagi Pelaku Riddah dengan Pendekatan Kebahasaan}

الُْفَفارِقُ Denambahan kata yang tidak terdapat pada hadits kedua, sudah menjadi kaedah umum bahwa penambahan lafad berimplikasi pada penambahan makna. Penambahan tersebut menjadikan beberapa ulama berbeda pula dalam memahaminya.

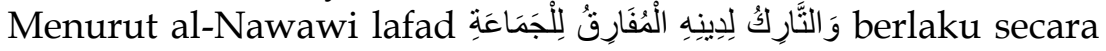
umum untuk laki-laki maupun perempuan, mereka harus dihukum mati jika tetap atas kemurtadannya setelah diminta untuk bertaubat . Al-Nawawi pun tidak memberi penjelasan berbeda terhadap

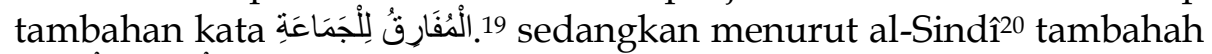
الُُْفَارِقُ لِلْجَمَاعَةِ berarti memisahkan diri dari jamaah muslimin karena sebab kemurtadannya tersebut.

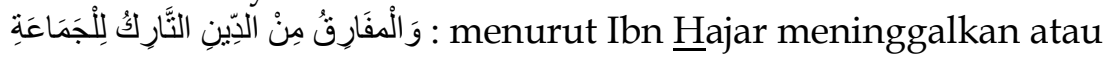
memisahkan diri dari jama`ah adalah satu sifat (sama) dengan meninggalkan agama. Meninggalkan jama`ah itu maksudnya adalah meninggalkan jama`ah muslimin itu sendiri, yaitu murtad dari agama. Karena kalau hal itu terpisah, maka hadits ini akan menyebutkan empat hal yang boleh dibunuh dan bukannya tiga. ${ }^{21}$

Dari tambahan kata pada hadits dia atas Ibnu Taimiyah berpendapat bahwa pelaku riddah terdapat dua macam:

1. Orang yang semata-mata murtad;

2. Orang murtad yang disertai dengan permusuhan Islam.

Untuk kasus pertama apabila diminta bertaubat kemudian mereka menyatakan bertaubat maka diterima taubatnya. Jika tidak, maka maka tidak ada hukuman lain yan gdapat menggantikan kecuali hukuman mati. Pendapat ini sesuai dengan pendapat jumhur tentang keharusan orang yang semata-mata murtad untuk diminta pertaubatannya sebelum hukumannya diberlakukan. Menurut

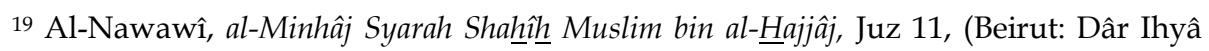
al-Turâts al-`Arabî, 1392 H.), 165.

${ }^{20}$ Muhammad bin `Abd al-Hâdî al-Taatwi Abû alhasan Nûruddîn al-Sindî, Hâsyiah alSindî 'Alâ Sunan al-Nasî'î..., Juz 7, 91.

${ }^{21}$ Alî Ibn Hajar al-Asqalânî, Fath al-Bârî..., Juz 12, 202 
madzhab Malikî dan Hanbalî hukuman mati ditunda tiga hari untuk diminta pertaubatannya. ${ }^{22}$

Kelompok kedua menurut Ibnu Taymiyah terkandung pada

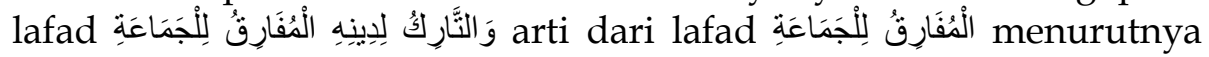
memusuhi atau memerangi orang- orang Islam, dan juga bermakna perbuatan kriminal. dapat dipahami kelompok kedua ini ialah orang orang murtad yang disertai dengan permusuhan dan perbuatann kriminal. Pemberlakuan hukuman mati bagi kelompok ini dilakukan secara langsung tanpa diminta untuk bertaubat terlebih dahulu. ${ }^{23}$

Yusuf Qardlawi ${ }^{24}$ pun membagi murtad menjadi dua kelompok namun implikasi hukum yang dipaparkan berbeda dengan penjelasan Ibnu Taimiyah. Menurutnya para ulama membedakan bid'ah antara ringan dan berat, membedakan pelaku bid ah antara yang mengajak ke perbuatan bid'ah tersebut (al-dầiyah) dan yang tidak (ghair aldâiyah). Semestinya dalam urasan pelaku riddah harus dibedakan pula mana yang ringan dan berat, serta mana yang mengajak kepada kemurtadan mana yang tidak.

Kemurtadan yang tergolong berat seperti kemurtadan Salman Rusdi yang memusuhi Islam dan mengajak kepada kemurtadan maka penerapannya pun harus keras pula seperti pendapat jumhur ulama, yaitu hukuman mati. Sesungguhnya murtad yang disertai ajakan pada kemurtadan, bukan hanya kafir terhadap Islam bahkan memusuhi dan memerangi Islam dan umatnya. Maka mereka termasuk golongan orang-orang yang memerangi Allah dan RasulNya serta membuat kerusakan di muka bumi. ${ }^{25}$ Menurut Ibn Taymiyah $^{26}$ memerangi terbagi dua, yaitu dengan tangan atau kekuatan dan dengan lisan, seringkali memerangi dengan lisan jauh lebih berbahaya dari memerangi dengan kekuatan, oleh karenanya Nabi saw. Karena efek bahaya dalam beberapa kasus nabi menghukum mati mereka.

\footnotetext{
22Ibn Taimiyah, al-Shârim al-Maslûl ‘ala Syâtim al-Rasûl, (Riyadh: al-Haras alMamlakah al-Su'ûdiyah, tth), 318-319.

23 Ibid.

24 Yûsuf Qardhawi, Jarîmah al-Riddah wa 'Uqûbah al-Murtad (Beirut: al-Maktab alIslâmî, 1998), 42-43.

25 Ibid.

${ }^{26}$ Ibn Taimiyah, al-Shârim al-Maslûl `ala Syâtim al-Rasûl... 385
} 
Murtad ringan yang tidak disertai permusuhan dan ajakan pada kemurtadan tentu hukumannya berbeda dengan murtad yang disertai permusuhan. Mereka tidak dihukum mati sebagaimana pelaku riddah berat, hukuman yang pantas untuk mereka adalah hukuman mati secara sosial dari masyarakat muslim. Mereka dikucilkan dengan cara tidak dilindungi, dicintai, dan ditolong dalam hal apa pun. Hukuman nampak sepele tapi sesungguhnya lebih berat bagi orang yang punya pikiran dan hati nurani daripada hukuman mati secara fisik. ${ }^{27}$

Mayoritas hadits-hadits tentang hukuman mati bagi pelaku riddah adalah hadits qaulî tidak dijelaskan sebab keriddahannya. Patut diduga jika riddah yang terjadi pada masa Nabi saw. yang dihukum mati merupakan pelaku riddah yang disertai permusuhan dan tindak kriminal seperti hadits fi lî pada kelompok hadits hadits ke-3. Sebagian ulama bahkan mengatakan bahwa tidak ada satu pun yang meriwayatkan bahwa Nabi saw. membunuh orang murtad. ${ }^{28}$ Pada hadits keempat, Nabi saw. memerintahkan untuk membunuh orang murtad karena disertai pembunuhan terhadap orang Islam dan tidak kriminal lainnya yaitu mencuri unta.

\section{Pemahaman Hadits-hadits tentang Hukuman Mati bagi Pelaku Riddah dengan Pendekatan Muqârin}

Menurut Ibrâhim al-Muth inî, perbedaan dalam had (hukuman mati) bagi para pelaku riddah, tidak pernah berbeda. Pendapat pada masalah hukuman mati bagi pelaku riddah dalilnya shahih dan dalahnya qath $i$. Contoh perbedaan yang terjadi dalam masalah riddah ini adalah perbedaan seputar istitâbah (tawaran/seruan untuk bertobat bagi pelaku riddah sebelum hukuman bunuh dijatuhkan) warisan yang ditinggalkan si murtad, perempuan yang murtad dll. Mayoritas ulama mengatakan istitâbah wajid dilakukan oleh penguasa yang menangani kasus tersebut, sedang sebagian kecil mengatakan bahwa istitâbah tidak wajib tapi sekadar dianjurkan (sunnah). Perbedaan yang lain adalah seputar orang murtad yang dibunuh. Mayoritas ulama berpendapat bahwa orang murtad jika tidak mau bertobat maka ia wajib dibunuh, baik laki-laki maupun perempuan

\footnotetext{
27 Yusuf Qardhawi, Jarîmah al-Riddah wa `Uqûbah al-Murtad... 44.

28 Ibid., 40.
} 
berdalil dengan keumuman lafadz $ن$ salam hadits di atas yang meliputi laki-laki maupun perempuan. Para pengikut madzhab Hanafi (hanafiyyûn) dalam hal ini berbeda pendapat dan mengatakan bahwa perempuan yang murtad jika tidak mau bertobat tidak boleh dibunuh tapi cukup dipenjara seumur hidup dan setiap hari diseru untuk bertobat. Landasan yang dijadikan dalil hanafiyyîn ini adalah; perempuan harbiyâh (perempuan yang golongannya terlibat permusuhan dengan kaum muslimin) tidak boleh dibunuh terjadi perang antara kaum perempuan tersebut dengan kaum muslimin. Masalah lain yang menjadi perbedaan adalah seputar harta warisan yang ditinggalkan oleh pelaku riddah. Pendapat terkuat mengatakan bahwa harta yang ditinggalkan pelaku riddah yang tidak bertobat lalu dihukum bunuh yang didapat saat ia Islam diserahkan kepada ahli warisnya. Adapun harta yang didapat saat ia dalam keadaan murtad maka peninggalan tersebut tidak diwariskan karena perbedaan agama saat ia mendapat harta tersebut. ${ }^{29}$

Al-Syâfi $i^{30}$ berpendapat barangsiapa (laki-laki dan perempuan yang telah baligh) berpindah keyakinan dari syirik ke agama Islam kemudian murtad maka terlebih dahulu harus diminta bertaubat. Jika ia bertaubat maka taubatnya harus diterima, namun jika tidak mau bertaubat maka ia harus dihukum mati. Menurutnya jika orang murtad tidak mau bertaubat maka ia dihukum mati dan hartanya menjadi rampasan bagi kaum muslimin.

Sedangkan dalam madzhab Hanafi, murtad terdiri dari beberapa macam; Pertama: murtadnya seorang laki-laki merdeka, maka ia harus diminta bertaubat jika tidak bertaubat maka dihukum mati; Kedua: jika yang murtad perempuan maka ia pun harus diminta bertaubat, jika tidak bertaubat maka ia harus dihukum penjara dan dipaksa untuk memeluk agama Islam kembali; Ketiga: murtadnya hamba sahaya laki-laki hukumnya seperti hukum laki-laki merdeka; Keempat: hamba sahaya perempuan jika murtad maka ia diminta bertaubat, jika tidak bertaubat maka hukumannya dipenjara dan dipukuli setiap hari sampai kembali memeluk Islam; Kelima: jika anak-anak murtad, secara hukum pun murtad, berbeda dengan

\footnotetext{
${ }^{29}$ Ibrâhim al-Muth inî, 'Uqûbah al-Irtidâd 'an al-Dîn Baina al-Adillah al-Syar iyah Wa Syubhâh al-Munkarîn, (Kairo: Maktabah Wahbah, 1994), 62-64.

30 Al-Syâfi `̂̀, al-Umm, Juz I, (Beirut: Dâr al-Ma`rifah, 1990), , 294.
} 
Syafi i yang berpendapat Islam dan murtadnya anak-anak secara hukum tidak dianggap apa-apa. ${ }^{31}$

Menurut madzhab Maliki, orang murtad diminta bertaubat selama tiga hari dari ditetapkan kemurtadannya dan selama masa itu ia diberi makan dari hartanya sendiri, jika tidak bertaubat maka dihukum mati dengan cara dipenggal lehernya dan tidak dimandikan serta dishalatkan jenazahnya. Tidak terdapat perbedaan hukum bagi orang merdeka atau budak, laki atau perempuan. Hanya saja harta orang murtad merdeka yang dihukum mati dianggap fay' sedangkan harta budak diberikan kepada tuannya. ${ }^{32}$ Jika yang murtad anak-anak maka ia harus diminta bertaubat untuk kembali masuk Islam ketika dewasa, jika tidak mau bertaubat maka berlaku baginya hukum riddah orang dewasa. ${ }^{33}$

Pemahaman para ulama klasik terhadap hadits-hadits tentang hukuman mati bagi orang murtad, tidak ada perbedaan satu dengan yang lain. Perbedaan hanya dalam bagian dari dalil tersebut seperti yang diungkapkan Ibrâhim al-Muth inî yaitu tentang kewajiban istitabah, pemberlakuan hukuman terhadap kaum perempuan dan terhadap anak-anak. Hal ini berbeda dengan ulama kontemporer yang lebih beragam dalam memahami hadits-hadits tersebut.

Mahmud Syaltut berpandangan bahwa pendapat ulama tentang hadits-hadits hukuman mati bagi pelaku riddah ${ }^{34}$ terbatas pada masalah-masalah berikut: 1 . Apakah yang dimaksud dengan 'barang siapa yang mengganti agamanya' khusus untuk orang Islam saja atau meliputi pula orang Nashrani yang masuk agama Yahudi misalnya? 2. Apakah hadits tersebut berlaku bagi laki-laki maupun perempuan, atau hanya berlaku bagi laki-laki saja dan jika yang murtad perempuan tidak dihukum mati? Apakah orang murtad langsung dihukum mati atau diminta untuk bertaubat? Apakah permintaan untuk bertaubat ada atau tidak ada masanya sehingga orang murtad selamanya diminta bertaubat?

31 Al-Sughdî, al-Nitfwa al-Fatâwwâ, Juz II, (Ammân: Dâr al-Furqân, 1984), , 290.

${ }^{32} \mathrm{Abu}$ `Abdillah al-Mâlikî, Mawâhib al-Jalîl Syarh Mukhtashar Khalîl, Juz IX, (Beirut:

Dâr al-Fikr, 1989), 2013.

33Ibid. Juz IIX, 62

${ }^{34}$ Mahmud Syaltût, al-Islâm Aqîdah wa Syarî̀ah, Vol. I, (Kairo: Dâr al-Syurûq, 1997), 280-281. 
Syaltut lantas menjelaskan bahwa tidak sedikit ulama berpendapat had tidak dapat ditetapkan dengan hadits ahad. Sematamata kafir dan murtad menurutnya bukanlah alasan untuk menghalalkan darah, sesungguhnya orang kafir dan murtad baru dapat dihukum mati jika kekafiran dan kemurtadan mereka diiringi dengan permusuhan terhadap terhadap kaum muslim dan menjelekjelekkan Islam. ${ }^{35}$

al-Qur'an dalam beberapa ayat melarang melakukan pemaksaan dalam hal keyakinan

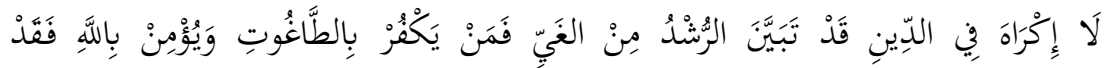

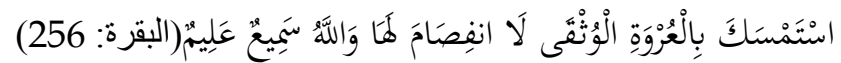

"Tidak ada paksaan dalam beragama, sesungguhnya telah jelas jalan yang benar dari jalan yang salah. Karena itu, barangsiapa yang inkar kepada thâghût dan beriman kepada Allah, maka sesungguhnya ia telah berpegang teguh kepada gantungan tali yang amat kuat yang tidak akan putus. Sesungguhnya Allah maha mendengar lagi maha mengetahui" (QS. alBaqarah 2: 256)

Ayat di atas mengandung pesan, tidak ada paksaan dalam menganut keyakinan suatu agama. Allah menghendaki agar seluruh manusia merasakan kedamaian, oleh karenanya agama Allah dinamakan Islam yang berarti damai. Kedamaian tidak mungkin diraih kalau jiwa manusia tidak damai. Paksaan jelas menyebabkan ketidakdamaian jiwa. Karena itu tidak ada paksaan dalam menganut agama Islam. Mengapa harus ada paksaan, padahal telah jelas jalan yang lurus dari jalan yang salah. Jika demikian, maka suatu yang wajar bila pejalan memilih jalan yang benar, dan tidak terbawa kepada jalan yang sesat. Sangatlah wajar bila semua orang memeluk agama ini dan pasti ada yang salah dalam jiwa seseorang yang enggan untuk memilih jalan yang lurus yang telah terbentang di hadapannya. ${ }^{36}$

Ada pendapat bahwa kebebasan untuk memilih keyakinan baik Islam maupun yang lain tidak ada hubungan dengan hukuman bagi pelaku riddah, karena kebebasan untuk memilih agama tidak berarti kebebasan untuk keluar setelah ia masuk Islam. Namun menurut Quraish Shihab, agama Islam pada dasarnya memberi kebebasan

\footnotetext{
35 Ibid.

${ }^{36}$ M. Quraish Shihab, Tafsîr al-Mishbâh, Vol. I, (Jakarta: Lentera Hati, 2003), 515.
} 
untuk memilih dari hal yang sekecil-kecilnya sampai yang sebesarbesarnya, yaitu memilih untuk beriman atau tidak beriman. Kalau pilihan itu baik, maka ganjaran yang akan diterima pun akan baik, demikian pula sebaliknya. Apabila pilihan itu buruk, maka keburukan pula yang akan didapat. Menurut Quraish Shihab lagi, kebebasan yang diberikan oleh Islam tentu termasuk di dalamnya kebebasan untuk berpindah agama. Kalau pemeluk agama lain boleh untuk berpindah ke dalam agama Islam, tentu secara logika, orang Islam pun logis untuk berpindah ke agama lain di luar Islam. ${ }^{37}$

\section{Pemahaman Hadits-hadits tentang Hukuman Mati bagi Pelaku} Riddah dengan Pendektan Historis, Sosiologis dan Antropologis

Pemberlakuan hukuman mati bagi pelaku riddah kemungkinan karena dua hal. Pertama: karena kemurtadan yang disertai dengan permusuhan dan tindak kriminal kepada umat Islam; Kedua: karena kondisi masyarakat saat itu belum memiliki landasan beragama dan berbangsa secara kuat. Hal ini karena asas negara pada masa-masa tersebut berbeda dengan asas negara pada masa sekarang. Pada saat itu asas dan identitas sebuah negara tidak terlalu jelas, agama adalah asas negara demikian juga agama adalah identitas kebangsaan seseorang. Seorang muslim merupakan penduduk bagi setiap masyarakat Islam dan juga anggota bagi setiap kelompok muslim, demikian halnya bagi seorang non muslim baik (musyrik, Yahudi atau Nasrani) di masyarakat non muslim dan kelompok non muslim. Masyarakat saat itu, juga hidup dalam kondisi perang kecuali antara satu pihak dengan yang lainnya mempunyai perjanjian untuk tidak bermusuhan dan tidak saling menyerang. Dengan kondisi seperti itu, maka seorang yang keluar dari agama saat itu, menyerupai pengkhianatan terhadap negara. Kondisi saat itu pun mengharuskan orang-orang yang murtad untuk meninggalkan negeri Islam dan bergabung dengan negara musuh. Karena ketika seorang meninggalkan agamanya ke agama yang lain, berarti ia telah pula bergabung dengan agama dan negara musuhnya. ${ }^{38}$

${ }_{37}$ M. Quraish Shihab, Wawasan al-Qur'an Tentang Kebebasan Beragama, artikel dalam buku Passing Over Melintasi Batas Agama, (Jakarta: PT. Gramedia Pustaka Utama, 1998), 190.

38 Lihat Muhammad Sa î̀d al-`Asymâwî, Ushûl al-Syarî‘ah, (Kairo: Maktabah Madbûlî al-Shaghîr, 1996), 131-132 
Dalam konteks kekinian dan ke-Indonesia-an hal ini menjadi sulit untuk dipahami, di mana identitas keagamaan dan negara tidak lagi menyatu antara satu dengan yang lain. Orang murtad pun pada masa kini tidak membuatnya otomatis bergabung dengan negara musuh. Berbeda jika kemurtadannya diiringi dengan permusuhan baik fisik maupun lisan kepada umat Islam sehingga memberikan efek negatif yang luas terhadap kaum muslim dan negara, maka saat itu bisa saja seorang imam memberlakukan kembali hukuman mati terhadap pelakunya. Pada konteks kekinian misalnya, negara-negara di seluruh dunia bersepakat tentang kebebasan beragama yang tertuang dalam piagam PBB berikut:

Konsep Hak Asasi Manusia (HAM) Pasal 18 The Universal Declaration of Human Right yang telah dirumuskan oleh Perserikatan Bangsa-Bangsa (PBB) pada tahun 1948 menyatakan bahwa: ${ }^{39}$

Everyone has the right to freedom of thought, conscience and religion: this right includes freedom to change his religion or belief, and freedom either alone or in community with others and in public or private, to manifest his religion or belief in teaching, practice, workship and observance.

Unsur-unsur kebebasan yang dapat diturunkan dari ketentuan pasal tersebut adalah:

a. Setiap orang mempunyai kebebasan atas pikiran, keinsafan batin dan agama, dalam hal ini termasuk kebebasan berganti agama atau kepercayaan.

b. Setiap orang mempunyai kebebasan untuk menyatakan agama atau kepercayaan dengan cara mengajarkannya, melaksanakannya, beribadat dan menaatinya.

Peristiwa perang riddah yang sering dijadikan acuan untuk membenarkan hukuman mati bagi pelaku riddah, lebih cenderung merupakan sebuah kebijakan pemimpin (karena alasan politis) dan bukan merupakan hukuman atas kemurtadan beberapa kabilah. Orang-orang yang diklaim murtad itu pada hakikatnya terbagi menjadi beberapa macam:

1. Orang yang memang tidak pernah memeluk Islam dan tetap dalam kekafiran seperti orang-orang yang mengaku nabi yaitu Aswâd al-'Unsî, Musailamah al-Kadzdzâb, dan Sajâh bint al-

\footnotetext{
39 Paul William (ed.), The International Bill of Human Righs, (Entwhistle books, Glen Ellen, 1991), 8.
} 
Arif Wahyudi

Hârits al-Taymah oleh karenanya mereka sebenarnya tidak dapat dikatakan sebagai orang murtad.

2. Orang-orang yang baru memeluk Islam dan belum benar-benar meyakini ajarannya, lalu mereka murtad mengikuti ajakan para nabi palsu atau bahkan mengaku-ngaku sebagai nabi sebagaimana Thulaihah ibn Khuwailid al-Asadî sebagaimana pimpinannya mereka juga mengadakan permusuhan dan penyiksaan terhadap kaum muslimin.

3. Orang-orang muslim yang takut oleh ancaman para nabi palsu sehingga mereka berpura-pura menjadi pengikut para nabi palsu tersebut. Mereka kembali bergabung ke kelompok muslim ketika pasukan Islam datang. Seperti Ibn `Amr al-Yasykarî seorang muslim dan pembesar Yamâmah yang membeberkan rahasia pasukan Musailamah kepada Khalid ibn Walid ketika datang untuk memerangi Musailamah di Yamâmah.

4. Orang-orang yang mengaku muslim namun menolak membayar zakat dengan berbagai macam alasan, di antaranya anggapan bahwa zakat hanya dibayarkan kepada nabi, setelah nabi tiada mereka menganggap bahwa kewajiban itu tidak ada lagi dan hanya merupakan sebuah upeti terhadap pemerintahan Madinah sehingga membuat mereka memberontak dan ingin merdeka. Ada juga yang tidak mau membai at Abu Bakar sebagai Khalifah karena tidak setuju dengan kepemimpinannya atau karena rasa ‘ashabiyah qaumiyah dan melihat kesempatan sepeninggal nabi untuk melepaskan diri dari kekuasaan pemerintah Madinah. ${ }^{40}$

Secara keseluruhan perang yang dilancarkan Abu Bakar tidak dapat dikatakan karena alasan untuk menegakkan hukuman mati bagi pelaku riddah, karena jelas bahwa mereka tidak pernah Islam untuk dikatakan murtad, kalaulah ada dari pengikut para mutanabbî yang murtad dari Islam berarti perang terhadap mereka bukan semata karena kemurtadan mereka tapi karena kemurtadan mereka disertai permusuhan mereka terhadap kaum muslimin.

\footnotetext{
40 Rajab Muhammad 'Abd al-Halîm, al-Riddah fi Dhau' Mafhûm Jadîd (Kairo: Dâr al-
} Nahdhah al-'Arabiyah, tth), 69 
Dari analisa di atas, penulis cenderung berpendapat bahwa hukuman mati bagi pelaku riddah adalah kebijakan politik imam dengan berbagai alasan.

1. Tafsir QS. al-Baqarah 2: 256 bahwa kebebasan untuk memeluk agama berarti pula kebebasan untuk keluar. Kalau pemeluk agama lain bisa berpindah ke dalam agama Islam, orang Islam pun logis untuk berpindah ke agama lain di luar Islam.

2. Sesungguhnya iman adalah pembenaran dengan hati sampai taraf yakin, permasalahan hati tentunya tidak ada yang dapat mengetahuinya kecuali Dzat yang Maha Mengetahui segala yang dhahir dan yang gaib, yaitu Allah, maka keimanan tentu tidak akan berbuah dari sebuah paksaan dan keterpaksaan.

3. Ahli Teologi bersepakat untuk mengatakan bahwa pernyataan keimanan tidak sah bila tidak dilakukan secara sukarela. Oleh karena itu, pengakuan keimanan secara terpaksa membuat iman itu tidak sah dan tidak ada artinya di hadapan Allah.

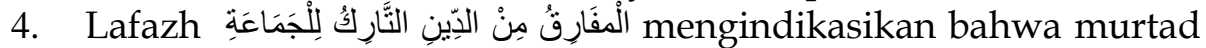
semata-mata tidak dapat dihukum mati, kecuali jika kemurtadannya diiringi dengan permusuhan dan tindakan kriminal. Hampir seluruh orang murtad yang dibunuh pada zaman Nabi, kemurtadannya disertai dengan tindakan kriminal dan permusuhan.

5. Saat itu kondisi masyarakat belum memiliki landasan beragama dan berbangsa secara kuat. Asas negara pada masa-masa tersebut berbeda dengan asas negara pada masa sekarang. Pada saat itu asas dan identitas sebuah negara masih sederhana. Agama adalah asas negara demikian juga agama adalah identitas kebangsaan seseorang. Seorang muslim merupakan penduduk bagi setiap masyarakat Islam dan juga anggota bagi setiap kelompok muslim, demikian halnya bagi seorang non muslim baik (musyrik, Yahudi atau Nasrani) di masyarakat non muslim dan kelompok non muslim. Masyarakat saat itu, juga hidup dalam kondisi perang kecuali antara satu pihak dengan yang lainnya mempunyai perjanjian untuk tidak bermusuhan dan tidak saling menyerang. Dengan kondisi seperti itu, maka seorang yang keluar dari agama saat itu, menyerupai pengkhianatan terhadap negara. Kondisi saat itu pun mengharuskan orang-orang yang murtad untuk meninggalkan negeri Islam dan bergabung dengan 
negara musuh. Dengan demikian tidak ada kemurtadan yang tidak disertai permusuhan saat itu.

6. Kebijakan Umar bin Khattab untuk tidak membunuh orang murtad, jika merupakan ketentuan Umar pasti akan menjadi orang yang paling keras dalam melaksanakan hukuman bagi orang murtad. Hal itu menandakan bahwa sabda nabi saw. tentang hukuman bagi pelaku riddah merupakan kebijakan nabi saw. yang berlaku sesuai situasi dan kondisi.

7. Penumpasan orang-orang murtad pada masa Abu Bakar lebih pada kebijakan politik untuk menumpas pemberontak dan menstabilkan negara. Orang-orang yang disebut murtad terdiri dari beberapa kategori, yaitu: 1. orang-orang yang sebenarnya tidak pernah memeluk Islam; 2. takut pada intimidasi pemberontak; 3. belum kuat imannya; 4. anggapan mereka bahwa zakat hanya wajib diberikan kepada nabi saw.

\section{PENUTUP}

Dari paparan sebelumnya dapat disimpulkan bahwa haditshadits tentang hukuman mati secara umum terdapat dua macam, Pertama: hadits qaulî yang berisi tentang sabda Nabi saw. "Barangsiapa yang berpindah agama maka bunuhlah". Ada pula beberapa riwayat dengan tambahan lafad "Meninggalkan agama dan berpisah dari jamaah muslimin". Pada hadits-hadits qauli tersebut tidak terdapat penjelasan lebih menjauh tentang murtad yang dihukum mati, meskipun pada hadits yang terdapat tambahan lafad beberapa ulama kemudian membuat kategori-kategori murtad yang dihukum mati. Kedua: hadits-hadits fi lî dari Nabi tentang beberapa orang murtad yang dibunuh karena kemurtadannya disertai dengan permusuhan dan tindak kriminal. Ada pula beberapa riwayat fi $i \hat{\imath}$ dari sahabat yang menghukum mati beberapa orang murtad berdasarkan pemahaman mereka terhadap hadits qaulî.

Rasulullah berkapasitas sebagai seorang imam ketika menyabdakan hadits-hadits tentang hukuman mati bagi pelaku riddah. Maka hukumannya merupakan ta zir yang berlaku temporer tergantung situasi dan kondisi. Jika dipandang oleh imam, riddah membahayakan negara dan akidah kaum muslim, ia berhak untuk menghukum dengan hukuman paling berat, yaitu dihukum mati. 
Sebaliknya jika dipandang tidak terlalu membahayakan, maka cukup dipenjara seperti yang dilakukan khalifah Umar bin Khattab.

\section{DAFTAR PUSTAKA}

'Asymâwî, Muhammad Sa'îd al-. Ushûl al-Syarî‘ah, (Kairo: Maktabah Madbûlî al-Shaghîr, 1996)

'Audah, Abd al-Qâdir. al-Tasyrî̀ al-Jinấî al-Islâmî Muqârin bi al-Qânûn al-Wadh '̂̀, (Kairo: Mu' assasah al-Risalah, tth)

'Imârah, Muhammad. al-Tafsîr al-Markisî li al-Islâm (Kairo: Dâr alSyrûq, 1996)

Abû Dawûd Sulayman bin al-Asy`ats al-Sijistanî. Sunan Ab̂̂u Dâud (Kairo: Dâr al-Risâlah, 2009)

Ali, Nizar. Memahami Hadits Nabi; Metode dan Pendekatan, (Yogyakarta: CsaD al-Rahman, 2001)

Asqalânî, Ahmad Alî Ibn Hajar al-. Fath al-Bârî, (Beirut: Dâr alMa`rifah, 1379 H.)

Atsîr, Ibn al-. al-Kâmil fi al-Târîkh (Beirut: Dar al-Fikr, 1965)

Baihaqî al-. Sunan al-Baihaqî al-Kubrâ (Mekah: Maktabah Dâr al-Bâz, 1994)

Bukhârî, al-. Shahîh al-Bukhârî (Beirut: Dâr al-Thauq al-Najâh, 1422 H.)

Cresswell, John W. Research Design Pendekatan Kualitatif, Kuantitatif, dan Mixed, ed. Terjemah oleh: Achmad Fawaid, cet. IV (Yogyakarta: Pustaka Pelajar, 2014)

Dilaga, Muhammad al-Fatih Surya. Metodologi Syarah Hadits, Vol I (Yogyakarta: SUKA Press, 2012)

Djazuli, A., Figh Jinayat Upaya Menanggulangi Kejahatan dalam Islam, (Jakarta: Raja Grafindo Persada, 1996)

Farmawi, Abu Hay al-. Metode Tafsir Maudhu i, ed. terjemah oleh Suryan A. Jamrah, (Jakarta: PT. Grafindo Persada, 19940)

Hajar, Ibn. Fath al-Bârî (Beirut: Dâr al-Ma`rifah 1379 H.)

Hakan, Zamsami Rum. Hukuman Mati Bagi Orang Murtad, Studi Sanad dan Matan Hadits-Hadits Riwayat anNasa'i (Skripsi UIN Sunan Kalijaga Yogyakarta)

Halîm, Rajab Muhammad 'Abd al-. al-Riddah fi Dhau' Mafhûm Jadîd (Kairo: Dâr al-Nahdhah al-`Arabiyah, tth)

Hanbalî, Ibn Qudâmah al-Dimasyqî al-. 'Umdah al-Figh (Beirut: Maktabah al-'Ashriyah, 2004) 
Ibrâhim al-Muth inî. 'Uqûbah al-Irtidâd 'an al-Dîn Baina al-Adillah alSyar iyah Wa Syubhâh al-Munkarîn (Kairo: Maktabah Wahbah, 1994)

Ma'lûf, Luis. al-Munjid fi al-Lughah al-A lâm, (Beirut: Dâr al-Masyriq, 2002)

Mahmûd Syaltût, al-Islam Aqidah wa Syarîah, Vol. I (Kairo: Dâr alSyurûq, 1997)

Mâlikî, Abu `Abdillah al-, Mawâhib al-Jalîl Syarh Mukhtashar Khalîl (Beirut: Dâr al-Fikr, 1989)

Mandzûr, Ibn. Lisân al-'Arab, (Beirut: Dâr Ihyâ' al-Turâts al-'Arâbî, 1999)

Mulyosudarmo, Suwoto. Kebebasan Passing Over Melintasi Batas Agama, (Jakarta: PT. Gramedia Pustaka Utama, 2001)

Munawir, Imam. Metode-Metode Penelitian Sosial (Surabaya: Usaha Nasional, tth.)

Naysabûrî, Muslim ibn al-Hajjâj Abu al-Hasan al-Qusyayrî. Shahih Muslim (Beirut: Dâr Ihyâ' al-Turâts al-`Arabî, tth.)

Nasâ'î al-. Sunan al-Nasâ'î (Halab: Maktabah al-Mathbû'ât alIslâmiyah, 1986)

Nawawî al-. al-Minhâj Syarah Shahîh Muslim bin al-Hajjâj (Beirut: Dâr ihyâ al-Turâts al-'Arabî, 1392 H.)

Qadiri, Abdullah Ahmad. Murtad Dikutuk Allah, terj. Salim Wakid, (Solo: CV. Pustaka Mantiq, 1992)

Qardlâwi, Yûsuf. Jarîmah al-Riddah wa 'Uqûbah al-Murtad (Beirut: alMaktab al-Islâmî, 1998)

Ridlâ, Rasyîd. Tafsîr al-Qur'an, al-ㅌakîm (Beirut: Dâr al-Ma`rifah, tth)

Sâbiq, Sayyid al-. Fiqh al-Sunnah, (Beirut: Dâr al-Kitâb al-'Arabî, 1987)

Shihab, M. Quraish. Tafsîr al-Mishbâh (Jakarta: Lentera Hati, 2003) Wawasan al-Qur'an Tentang Kebebasan Beragama, artikel dalam buku Passing Over Melintasi Batas Agama (Jakarta: PT. Gramedia Pustaka Utama, 1998)

Shna anî, Abû Bakr bin Abd al-Razzâk bin Hammâm bin Nâfi al-. Al-Mushannif (Beirut: al-Maktab al-Islâmî, 1403 H.)

Sindî, Muhammad bin 'Abd al-Hâdî al-Taatwi Abû al-Hasan Nûruddîn al-. Hâsyiah al-Sindî 'Alâ Sunan al-Nasî'î (Halab: Maktab al-Mathbû ât al-Islâmiyah, 1986)

Sughdî al-. al-Nitf wa al-Fatâwâa, (Ammân: Dâr al-Furqân, 1984)

Syafi'î al-. al-Umm (Beirut: Dâr al-Ma`rifah, 1990) 
Syaltût, Mahmud. al-Islam Aqidah wa Syarîah (Kairo: Dâr al-Syurûq, 1997)

Taymiyah, Ibn. al-Shârim al-Maslûl 'ala Syâtim al-Rasûl (Riyadh: alHaras al-Mamlakah al-Su'ûdiyah, tth)

Tirmidzî, Muhammad bin 'Îsa bin Tsaurah bin Musâ bin al-Dhahhâk al-Tirmidzî. Sunan al-Tirmidzî (Kairo: Syirkah Maktabah wa alMathbû’ah Musthafâ al-Bâbî al-Halabî, 1975)

Umar, Nasaruddin. Deradikalisasi Pemahaman Al-Qur'an dan Hadits, Vol. I (Jakarta: PT. Elek Media Komputindo, 2014)

Zuhaylî, Wahbah. al-Figh al-Islâmî wa 'Adillatuh, (Beirut: Dâr al-Fikr, 1996)

Zuhri, Muhammad. Telaah Matan Hadits (Yogyakarta: Lembaga Studi Filsafat, 2003)

http://m.republika.co.id/indeks/hot_topic/camellia \%20shehata $\% 20$ guncang $\% 20$ mesi

CD Mausû̀ah al-Hadîts al-Syarîf (Kuwait: Global Islamic Software Company, 2000) 